Historic, Archive Document

Do not assume content reflects current scientific knowledge, policies, or practices. 



\section{DESCRIPTIVE PRICE LIST}

\section{Improved Varieties of Chestnut and Walnut}

\section{E. A. RIEHL, Godfrey, Illinois}

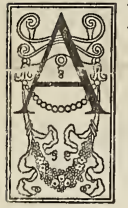

LL kinds of nuts are becoming more in demand as our population increases and the wild supply diminishes. Especially is this true since nuts are coming more and more into use as an article of food. In sections where the chestnut does not grow wild, it is free of all insect pests or diseases. Even San Jose scale does not harm it. The chestnut blight, which threatens to wipe out all the chestnut forests, need not be feared where the chestnut does not grow in the surrounding forests, provided growers do not make the mistake of buying trees from Eastern nurseries where the blight has spread. In the forty years that I have grown chestnuts, I have not seen a dozen nuts that had a worm in them, nor do I think it likely that they will be introduced for many years to come. The native chestnut forests are too far away, and artificial plantings too few and scattered to form a bridge.

The market for chestnuts is not likely to be fully supplied for many years, if ever. The prices for first class nuts are excellent. My crop, the last two seasons, sold readily in Chicago for 40 to 45 cents per pound, wholesale.

I know of no more promising horticultural proposition than chestnut growing. I have planted thousands of trees and am still planting, confident they will pay me better than anything else would. Lands too broken for cultivation can be planted to chestnut with great profit, and when the trees are large enough, can be pastured. However, if chestnuts are planted on good orchard land and well cultivated, they will make better growth and produce profitable crops much sooner.

I have on my premises a native chestnut tree, planted in 1863 , that is between 60 and 70 feet high, and 7 feet 6 inches in circumference. It has borne regular crops ever since coming into bearing. I make this statement simply as evidence that the chestnut will thrive in sections where the soil is right, that is, where there is good drainage and not underlaid with hard pan. The common American chestnut is too small and requires too long to come into bearing to be worthy of planting, especially as we have others that are larger, come into bearing earlier and are of fine quality.

About thirty years ago I became interested in nut culture, procuring nuts from all parts of the country that I heard of as promising, and that could be procured, among them some twenty-five varieties of chestnut. Most of these were of Japan strain, and of too poor quality. The Paragon is a good nut but it has the fault of over-bearing so as to dwarf the tree and often causing it to die, also the 
burr does not open readily and to get the nuts they must be threshed or dug out by hand. For these reasons I do not grow or propagate it. The following varieties have been found better and are the ones I grow and recommend:

\section{PARRY}

The earliest variety to ripen. Nut of largest size and very good quality. Tree a good grower and bearer. No planting should be without this variety.

\section{CHAMPION}

A seedling of Rochester, grown by me. Planted on rough uncultivated land that has never had a plow in it, yet the tree has uniformly borne good crops of large nuts of finest quality. I think this one of the very best chestnuts yet produced.

\section{PROGRESS}

A seedling of Rochester, originated by me, and fruited for several years. The nut is large, of excellent quality. The tree is a good grower and excellent bearer; better than the older varieties. Am planting it largely.

\section{FULLER}

Also a seedling of Rochester, originated by me. One of the best in quality of any cultivated chestnut. Tree a fine grower and good bearer. Worthy extensive planting.

\section{RUSH CHINQUAPIN}

A near relative to the chestnut, but small, sweeter than any chestnut. Tree small, early bearer, often bears in nursery row. Too small for commercial planting. Fine for home grounds.

\section{Black Walnuts}

\section{THOMAS}

This variety of the black walnut was originated in Pennsylvania. A tree procured fifteen years ago, and others propagated and grafted onto wild stocks, have borne well. Nut large, kernel large and of excellent quality, cracking quality excellent, ninety per cent coming out in halves and quarters, producing ten pounds of meat to the bushel, which sell at fifty to eighty cents per pound. I think this one of the best nuts to plant in this section for profit.

\section{STABLER}

Smaller than Thomas, cracks even better, most of the kernels coming out in halves, very promising.

I am not in the nursery business, and have no other stock to sell. 
Do not plant seeds or seedlings of chestnuts, or any other nut, expecting to get trees that will bear nuts of the same quality. They will vary just as much as apple, pear, peach or any other fruit. It does not pay to plant seedlings, unless it is the intention to bud or graft later to known good varieties. Chestnuts do not bear well unless two or more varieties are planted near each other, as they need cross pollenization.

While nut trees are high in price, when considered at the price per tree, they are no higher in price than fruit trees when it is considered that they are planted farther apart (40 to 60 feet) and that they live and bear profitable crops for a hundred years or more.

Nut trees being high priced it pays to take the best possible care of them after planting. Most trees die from drouth the first summer after planting. I strongly advise mulching with old straw or other litter, a space of not less than six feet in diameter and six inches deep. This will hold the moisture during almost any dry season.

\section{PRICES :}

$\begin{array}{lccccc}\text { Parry Chestnut, } & - & - & - & - & \$ 2.50 \text { each } \\ \text { Champion Chestnut, } & - & - & - & 2.50 \text { each } \\ \text { Progress Chestnut, } & - & - & - & - & 2.00 \text { each } \\ \text { Fuller Chestnut, } & - & - & - & - & 2.00 \text { each } \\ \text { Rush Chinquapin, } & - & - & - & 2.50 \text { each } \\ \text { Thomas Black Walnut, } & - & - & - & 2.00 \text { each } \\ \text { Stabler Black Walnut, } & - & - & - & 2.50 \text { each }\end{array}$

The above prices include packing when order amounts to $\$ 5$ or more.

On receipt of 50 cents I will mail postpaid to any address in United States samples of collection of chestnuts and Thomas walnut.

Nurserymen and large planters please write for special quotations.

E. A. Riehl, Godfrey, Ill. :

Brooklyn, N.Y., Oct. 19, 1919.

Chestnuts received yesterday. Fine! Agreeably surprised by flavor. Did not know any cultivated varieties were nearly so good.

Yours sincerely,

J. LEWIS PETTMER.

Dear Mr. Riehl : -

Lancaster, Pa., Nov. 1, 1915.

You have them all skinned to a finish on fine chestnuts. The growing of chestnuts now in localities not likely to get the blight, offers very attractive inducements. I think I would prefer Progress chestnuts to any other of your seedlings. This has the real look and quality of the American sweet chestnut, and its light color makes it more attractive I think. Fuller would be my second choice.

Very truly yours,

J. F. JONES. 
The trees planted in 1914, mostly Rochester variety, are doing splendid. We do not believe in letting a tree bear too young, so that this season we really had our first nuts. Two trees together gave over twenty pounds and the nuts were splendid. In fact we believe there is a splendid future ahead in our sections for chestnut culture.

Yours truly,

E. A. BOLSTER.

United States Department of Agriculture, Bureau of Plant Industry.

Dear Mr. Riehl : -

Washington, D. C., March 23, 1915.

The chestnuts which you sent me about the middle of October were held in cold storage until about a month ago. Several of us agreed that the one we have wanted to call "Riehl," that is seedling No. 20, (later named Fuller) is the most delicately flavored of any. It is a little sweeter, though not so large as Rochester. It has a brighter color and is therefore a little more attractive in appearance. Apparently these nuts are the best keepers in the lot, for although they have stood on my desk for fully a month, the kernels are now soft enough to be eaten readily. With kindest regards, I am,

Very sincerely yours,

C. A. REED,

In charge of nut culture investigations.

Dear Sir :-

$$
\text { Hamburg, Iowa, July 31, } 1920 .
$$

The chesnut trees I got of you last Spring are doing fine. Too good I think, as they are bearing from 3 to 18 burrs each. Shall I take these burrs off or let them mature?

Yours,
J. F. C. FINNELL.

UNITED STATES DEPARTMENT OF AGRICULTURE

BUREAU OF PLANT INDUSTRY

Washington.

Mr. E. A. Riehl,

October 21, 1921.

Dear Mr. Riehl :

Alton, Ill.

I greatly enjoyed my visit at your place and am fully convinced that chestnut culture is entirely practical under your conditions. We have few nuts here this year and they are greatly injured by weevils.

With kindest regards to your family, I am,

Very truly yours,

W. VAN FLEET, Plant Physiologist. 